\title{
Sediment Cyclicity and the Carnian Pluvial Episode: Evidence from Spectral Gamma-ray Logging of the Mercia Mudstone Group, SW England
}

\author{
A. Ruffell(1),W. M. Kürschner ${ }^{(2)}$
}

(1) School of the Natural Built Environment, Queen's University, Belfast, N.Ireland, UK, BT7 1NN (2) Department of Geosciences, University of Oslo, POB 1047 Blindern, 0316 Oslo, Norway

\begin{abstract}
The Late Triassic exposed on the Devon coast (SW England) is analysed through spectral gamma-ray logging and considered in terms of two theories of palaeoenvironmental change: sediment cyclicity and the Carnian Pluvial Episode (CPE). A decrease in total count gamma-ray output occurs at the CPE and reflects a geographically extensive change in depositional styles from siltstones and isolated playa-lake, evaporitic mudstones to more geographically-widespread evaporite-bearing mudstone cycles. Th/K and Th/ $\mathrm{U}$ ought to increase (through humid weathering) in the CPE, but these ratios do not change until above the CPE-related Dunscombe Mudstone Formation. A delayed response in Th enrichment is considered likely, reacting to both the initiation of the $1.2 \mathrm{my}$ long $\mathrm{CPE}$, but also longerterm and widespread Carnian rifting, marine inundation and volcanism in Pangaea.
\end{abstract}

Keywords:Triassic, Carnian Pluvial Episode (CPE), spectral gamma-ray, palaeoclimate.

\section{Ciclicidad sedimentaria y el Evento Pluvial Carniano: Evidencia desde las diagrafías de rayos gamma espectral del Mercia Mudstone Group, suroeste de Inglaterra}

\author{
RESUMEN
}

Los afloramientos del Triásico Superior de la costa de Devon (suroeste de Inglaterra) se analizan a través de las diagrafías de rayos gamma espectral y se consideran de acuerdo a dos teorías de cambio paleoambiental: ciclicidad del sedimento y el Episodio Pluvial Carniano (CPE). En el CPE se observa un descenso en la medida total de rayos gamma y refleja un cambio en un ámbito geográfico amplio en los estilos deposicionales de argilitas evaporíticas en playa-lake aislados a ciclos de argilitas con evaporitas y geográficamente más extensos. Los ratios Th/k y Th/u deberían aumentar (mediante meteorización húmeda) en el CPE, sin embargo estos ratios no cambian hasta por encima de la Dunscombe Mudstone Formation relacionada con la CPE. Un retardo en la respuesta en el enriquecimiento en Th se considera con gran plausibilidad, como reacción tanto al inicio del largo CPE de 1.2 ma, como al duradero y generalizado rifting en el Carniense, inundación marina y vulcanismo en Pangea.

Palabras clave: Triásico, Episodio Pluvial Carniano, rayos gamma espectrales, paleoclima. 


\section{Introduction: Cyclicity in the Mercia Mudstone Group (Late Triassic)}

Two dominant observations of the peri-North Atlantic LateTriassic are considered here: the orbital-precessional cycles of the Newark Supergroup (Eastern Seaboard of North America: see Olsen, 1984 and Olsen et al., 1996; Olsen and Kent, 1999; Kemp and Coe, 2007) and the Carnian Pluvial Episode (or CPE- see Dal Corso et al., 2018). The two have been considered together by Miller et al. (2017) for the CPE specifically, but not the overall changes in cyclicity through the LateTriassic, which we consider here, using spectral gamma-ray data.

Tucker and Benton (1982) envisaged three facies groups (hence the original 'Triassic' from von Alberti in 1834) for much of the global non-marine Triassic: First the sandstone-dominated 'Bunter' (NW Europe) or 'Moenkopi' (Arizona and SW USA) style; second the carbonate-dominated 'Tethyan'-style platforms and carbonates (Muschelkalk, San Cassian Dolomites, Tianjingshan/Maatang [China], Chomule [Himalayas]) and third, the mudstone-siltstone-evaporite-paleosol cyclic sequences redolent of the redbed Chinle and 'Keuper' style and lacustrine 'Newark' style deposits. In all three broad facies groups, basin-margin coarse clastics occur throughout the late Triassic, or at discrete intervals (e.g. Manuel Sandstones of Iberia, see Arche and Gomez-Lopez, 2014). Many locations show the interdigitation of each, with evaporites intercalated with limestones (e.g. some North African successions) or marine facies in marginal marine locations (e.g. southern Germany).

The pioneering work of Olsen (see for example Olsen, 1984 and Olsen et al., 1996; Olsen and Kent, 1986) demonstrated the existence of Milankovitch Cycles in the lacustrine-dominated Triassic of the Newark Supergroup. The Keuper facies (Ladinian-Norian) of NW Europe is often overlooked in broad reviews of Phanerozoic stratigraphy, appearing as a thick (up to $2 \mathrm{~km}$ ) succession of monotonous red-beds, between the more obviously cyclic Bunter sandstones below and Jurassic limestone-shale rhythms ('Lias') above. In reality, cyclicity was recognised in the Keuper (to become Mercia Mudstone Group - see Howard et al., 2008) by many authors, most relevant to the locations in the British Keuper in this work, by Arthurton (1980) and Elliot (1961) and in the German Keuper studies by Rheinhardt and Ricken (2000) and by Vollmer et al (2008). Equally innovative to the work of Olsen (op cit.) is the work of Kemp and Coe (2007) and Miller et al. (2017), who quantified the sediment cycles of the Mercia Mudstone Group in the succession logged here (Fig. 1), in terms of orbital-forcing. Only with hindsight is it perhaps unsurprising that the Milanko- vitch Band orbital cycles so redolent of the Lower Jurassic Lias (Weedon et al., 1999) are also present (in a different facies) in the LateTriassic: both were deposited in the monsoonal heart of Pangaea following the Variscan Orogeny, when seasonal and post-Variscan denudational fine-grained and carbonate deposition dominated NW European basins.

\section{Late Triassic Palaeoenvironmental Changes of NW Europe}

We may consider the LateTriassic Keuper environment of NW Europe in terms of three facies changes to the overall cyclic depositional environment, described by Milroy et al. (2019) as (from base to top): (1) blocky claystones of pedogenic and saline lake origin; (2) interbedded fine, grey sandstones and blocky blue mudstones from lacustrine/fluvial deposition and (3) silty, evaporitic playa lake mudstones. The Triassic timescale and stratigraphy of the section studied is shown in Figure 1. The age of the four formations of the Mercia Mudstone Group are considered by Howard et al. (2008) to be: Sidmouth Mudstone = roughly Ladinian; , Dunscombe Mudstone $=$ roughly Carnian Branscombe Mudstone $=$ early $/$ middle Norian and Blue Anchor Formation = late Norian to Rhaetian (pars). These agedates are largely based on palynomorphs (Warrington and Scrivener, 1980), whose isolated occurrence make it entirely possible that time-gaps occur in the succession. Miller et al. (2017) and Baranyi et al. (2018) provide further age-constraint of the Dunscombe Mudstone Formation, suggesting it to be of Julian (lower Carnian) age. The Ladinian Sidmouth Mudstone Formation is laterally-variable from basin-margin coarse clastic deposition, through siltstones, blocky red mudstones and evaporites in basins (the Blocky Claystone Facies of Milroy et al. [2019]) such as studied here. Second, at outcrop in Devon the Carnian Stage is represented by the Dunscombe Mudstone Formation, mudstones with mixed evaporites including halites and lenticular fluvial-deltaic sandstones. The Late Triassic (post-Carnian) 'Mercia/Keuper' facies of NW Europe is dominated by cyclically-arranged blocky calcreted red mudstones and siltstones, deposited in lacustrine playa systems (Hounslow et al., 2012: the Silty Mudstone Facies of Milroy et al. [2019]), with coarse clastic deposits adjacent to actively-rifting basin-margin settings e.g. (Greenland, Scottish-Shetland uplands, Fennoscandia). In the third and fourth parts of the succession studied here, this phase of the Late Triassic is represented by the blocky mudstones and anhydrites of the Branscombe Mudstone Formation and cyclic carbonate-mudstones of the Blue Anchor 


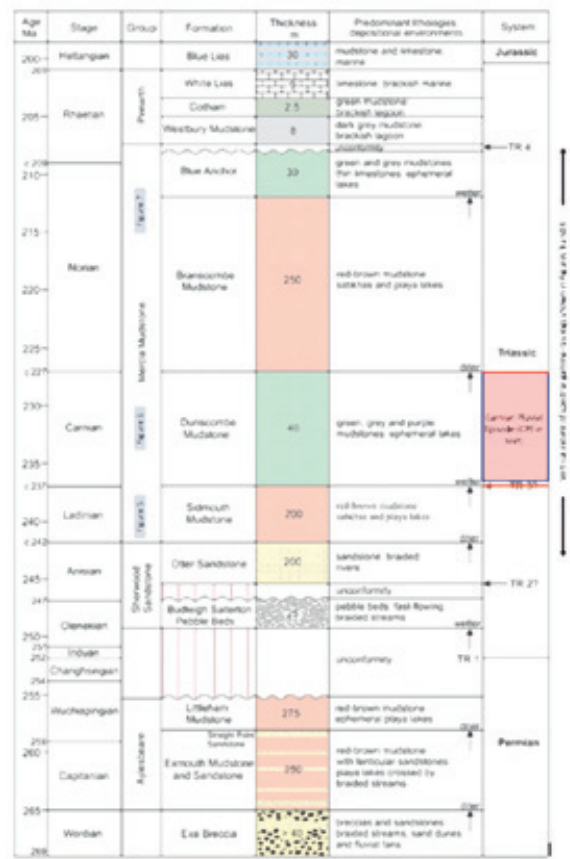

Figure 1. Triassic stratigraphy, with ages of the Devon (SW England) lithostratigraphic succession, after Howard et al., 2008 and modified after Gallois (2018), including TR1-TR4, considered widespread tectonic events in NW Europe. Stratigraphic location of oblique photographs showing sediment cyclicity shown in blue highlight in the 'Group' column.

Figura 1. Estratigrafía del Triásico, con edades de la sucesión litoestratigráfica de Devon (SE de Inglaterra, según Howard et al. (2008) y modificado de Gallois (2018), incluyendo TR1-TR4, considerados eventos tectónicos generales in el NW de Europa. La localización estratigráfica de las fotografías oblicuas mostrando ciclicidad sedimentaria se muestran resaltadas en azul en la columna "Grupo".

formations (Fig. 1). Hounslow et al. (2012) suggest the carbonates represent paleosol-dominated deposition and less-calcareous red siltstones reflect aeolian deposits with mud-cracking and rip-up clasts. This cyclicity begins in the pre-Carnian, and assumes dominance in the Norian Stage, representing wetting and drying episodes, implying an increasingly-evident climatic control on deposition. This wetting-drying cyclicity started to be established in the pre-Carnian; was interrupted in the CPE and then resumed in full in the long Norian (although see Lucas et al., 2012 on the 'Long Norian'). So what happened in the Carnian?

\section{Carnian (Late Triassic) Palaeoenvironmental Change}

The Carnian Pluvial Episode (sensu Dal Corso et al., 2018) was first identified as a major palaeoenvironmental change in the late Triassic by Schlager and Schöllnberger (1974), who termed the interruption of carbonate deposition by a clastic interval in the European Alps, the 'Rhinegraben Turnover' (op cit., p.166). Following this, Kozur (1975) suggested the Carnian succession of the German Alps and marginal/non-marine North German Basin, represented a wetter climate. Tollman (1976) recognised a fluvial-derived siliciclastic influx at the (Carnian) Julian 1 - Julian 2 boundary, seen as a possibly more wet interval. Visscher and Van der Zwan (1981) further analysed this interval in Europe, relating hygrophytic palynofloras to the extensive coals found in the Carnian. Tucker and Benton (1982) related the sedimentary record to biotic changes, especially in reptiles (including the early dinosaurs, or more correctly, Dinosaurids), leading to the more-cited origin of the Carnian Pluvial Episode (also, erroneously, 'phase' and 'event') in Simms and Ruffell (1989). Two subsequent publications indicated support for this palaeoclimate change: (1) the abundance of fossil wood in the Petrified Forest Member (Litwin et al. 1991) and (2) the large fluvial system generating a clastic influx into the Tethys (Aigner and Bachmann (1992). Subsequent research and publications have shown that the Petrified Forest Member is younger than the humid episode (Kent et al., 2018; Olsen et al., 2018) and increased humidity occurred in the underlying Shinarump Formation (Lucas and Tanner, 2018). However, sedimentological evidence for a pluvial event, such as the presence of fluvial deposits and its palynofloral content in the German Keuper, also known as the Schilfsandstein of the Stuttgart Formation, has been controversially discussed by Visscher et al. (1994) and later again by Franz et al. (2018). The humidity or pluvial theory lay more or less moribund to the early 2000s, when Gianolla et al. (1998) identified amber from the Carnian of the Italian Alps and Roghi (2004, p. 32) found support for a 'pluvial event' in Swiss Alpine palynology and most especially revisited Visscher and Van der Zwan's (1981) link between local hygrophytic palynofloras, coals and raised water-tables, in support of a pluvial episode. From 2004, over 50 publications have occurred (summarised in Dal Corso et al., 2018) that directly invoke the CPE (additionally termed 'Middle Carnian Wet Intermezzo' by Kozur and Bachmann, 2010) as a trigger for Carbon isotope changes, biotic extinction and radiation (probably most popularly in the Dinosaurids, see Bernardi et al., 2018). The shift in global ocean systems from a Cretan world of shallow biocalcification (the more Palaeozoic-style seas) to pelagic (a more Jurassic/Cretaceous [to modern times]-style "Cretan" ocean): the 'Mid-Mesozoic Revolution' of Ridgwell (2005) evolved through the lateTriassic, with dominance in the Carnian and a complete change in the early Jurassic (Preto et al., 2013).

Few studies have documented the cyclicity in marine Carnian deposits in the Tethyan realm and particular through the CPE. Zhang and co-workers 
(2015) established a cyclostratigraphic and magnetostratigraphic framework for the Carnian marine sediments of the Yangtze Platform in South China at the north-eastern margin of the Tethys. Based on gamma-ray logs they revealed a persistent series of sedimentary cycles consistent with the ratios of orbital-climate oscillations caused by long-eccentricity (405 kyr), short-eccentricity ( 100 kyr) and precession $(20 \mathrm{kyr})$. At the western Tethys margin, Mueller et al. (2016) studied the $450 \mathrm{~m}$ thick siliciclastic succession of the Reingraben and the Lunz Formations of the Northern Calcareous Alps (Austria) in detail for palynology and C-isotope stratigraphy. They showed changes in xerophytic (dry) versus hygrophytic (wet) palynofloral elements indicating a predominantly wet period. Superimposed on this long-term humid period were higher order fluctuations in the palynological assemblages, indicating pronounced wet-dry cycles with a ca 400 kyr periodicity although a precise cyclostratigraphic analysis needs to confirm this preliminary interpretation. Chua et al. (2020) recognised orbital cycles in the late Triassic of the Ordos Basin, China, further indicating the influence of Milankovitch periodicity in the megamonsoonal Triassic palaeoclimate in what is now modern-day China.

The cause of the CPE has most definitively been linked (using C-isotopes) by Dal Corso et al. (2012) to the Large Igneous Province eruptions of Wrangellia (present-day Alaska), with or without the influence of marine transgression (Franz et al., 2014), which, originally identified as platform drowning by Schlager and Schöllnberger (1974) was the beginning of the theory. A criticism of the CPE theory (Ruffell et al., 2015 ) is that the evidence is primarily derived from the present-day, and Triassic position, of the northern-latitude continents and peri-Tethyan successions: in addition, the authors considered 'Humid Episode; (op. cit., p.271) more appropriate, yet the term 'pluvial' (Dal Corso et al., 2018, p. 49) remains more popular. Unconscious bias may be at work, with the CPE affording such popularity (see above), that the absence of its change in the Gondwanan successions is ignored in favour of the positive determinism involved in analysing the presence and nature of the $\mathrm{CPE}$ in already-known successions. Exceptions to this do occur, most notably the record of changes in Triassic aeolian dust, recorded by Nakada et al. (2014) from present-day Japan, which was situated in the Panthalassic ocean.

These global palaeoenvironmental changes maybe reflected in the succession studied (the Devon coast, southern England) through clay mineralogy and $\mathrm{C}$-isotopes. The records of clay minerals (Jeans, 1978), show the abundance of smectites and palygor- skite through the humid phase with an appearance of sepiolite above: Rostasi et al. (2011) recorded a similar influx of smectite in the Carnian of Hungary, interpreted as due to the humid climates. Carbon isotope analysis of the section studied here, by Miller et al. (2017) showed five negative shifts through the suggested humid phase, consistent with global records.

If we now take the review of changes in Mercia/Keuper facies cyclicity (above), together with the evolving theory of the CPE, we see that the rise in Keuper/ Mercia cyclicity had its beginning in pre-Carnian times and took hold after, when a major change in the whole Earth ocean-land ecosystem occurred synchronously to the rifting and breakup of Pangaea, with attendant marine transgressions and volcanism.

\section{Spectral Gamma-ray Logs - Overview}

Potassium (K), uranium (U) and thorium (Th) isotopes provide the bulk of the total natural gamma-ray count in rocks. The total count, and the those of these three elements can be measured non-destructively and in real time, such as at outcrop or in a borehole, using a spectral gamma-ray detector (Slatt et al., 1992). Phanerozoic sedimentary successions often show systematic changes in $\mathrm{K}, \mathrm{U}$ and Th contents that appear to compare to other indicators of sea-level change, diagenesis and palaeoclimate change in the hinterlands. In sections dominated by kaolinite, smectite/ mixed smectite-illite and illite, (with subordinate chlorite), systematic and widely-correlated (over hundreds of $\mathrm{km}$, with other proxy data) changes to $\mathrm{K}, \mathrm{U}$ and Th contents have been ascribed to variations in hinterland weathering, and thus palaeoclimate change (Ruffell and Worden, 2000). When successions with unusual clay minerals, heavy minerals, black shales or carbonate are measured, the $\mathrm{K}, \mathrm{U}$ orTh distribution becomes difficult to interpret (Hurst, 1990; Ruffell and Worden, 2000; van Buchem et al., 1992): a particular issue for this study (see below). $\mathrm{K}$ is common in many sediments that bear orthoclase and microcline feldspars $\left(\mathrm{KaISi}_{3} \mathrm{O}_{8^{\prime}}\right.$ muscovite mica $\left(\mathrm{H}_{2} \mathrm{KAI}\left(\mathrm{SiO}_{4}\right)_{3}\right.$ or clays. $U$ and Th have a number of host minerals in sedimentary rocks including clays, heavy minerals, phosphates and organic matter. Whilst the various clay species have different sites for $U$ and Th, there is evidence to support some relationship between i) detrital kaolinite/mixed-layer illite-smectite and $U$ or ii) detrital illite with Th (Myers and Bristow, 1989 and Slatt et al., 1992) as well as with different heavy minerals (Hurst, 1990). The main complication in this simplistic view is that Th and $U$ are commonly found in inclusions within clays and micas and not as part of the crystal structure 


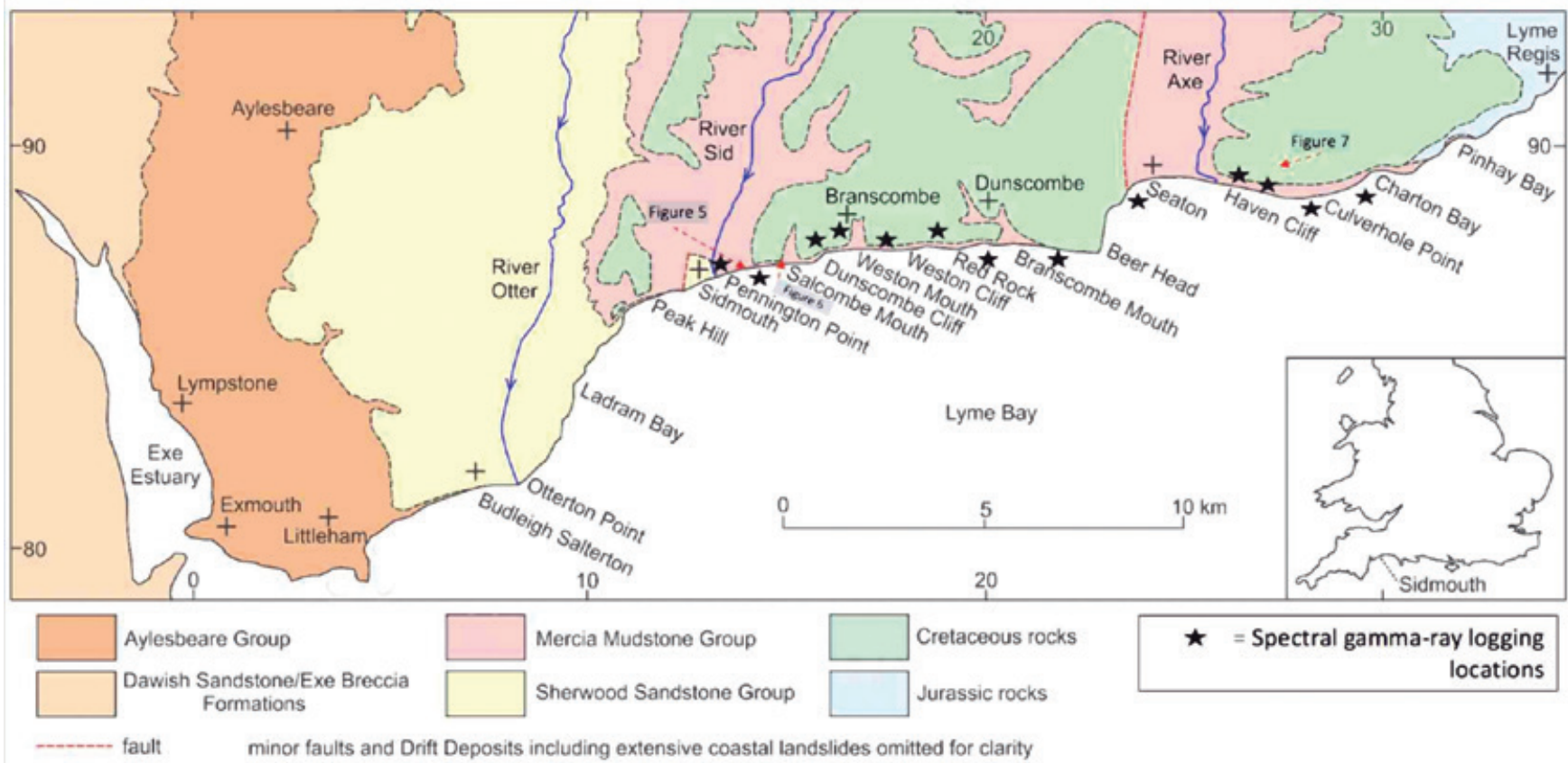

Figure 2. Geographic location of the section studied, with gamma-ray logging locations (* motif) and locations of field photographs (shown in Figures 5, 6 and 7) with blue highlight. Modified after Gallois (2018).

Figura 2. Localización geográfica de la sección estudiada, con las localizaciones (*) de las diagrafías de rayos gamma y las localizaciones de las fotografías de campo (mostradas en las figuras 5, 6 y 7). Modificado de Gallois (2018).

itself (Hurst, 1990). This relationship is not detectable without recourse to petrography. The $U$ and Th content of sediments is undoubtedly also influenced by the presence of other minerals, especially those of the heavy mineral suite, as suggested by Myers and Bristow (1989) and Hurst (1990). Regardless of these complications, log-motif analysis of gamma-ray signatures is now standard practice in stratigraphic analysis for detection of sediment cycles/parasequences and identification of key boundaries such as flooding surfaces, both from outcrop and subsurface datasets (Nazeer et al., 2016). A change in palaeoclimates, from the variably-cyclic Anisian-Ladinian, through humid Carnian, to strongly cyclic Norian should provoke a change in gamma-ray output from the sediments, most specifically, the humidity of the CPE should show an increase in $\mathrm{Th} / \mathrm{K}$ and Th/U ratios, if the unusual clay minerals of the Mercia Mudstone Group record this, and if this change really occurs: we test these assumptions below.

\section{Spectral Gamma-ray Logging of the Mercia Mudstone Group, SW England}

\section{Method}

The type section for the $\sim 520 \mathrm{~m}$ thick Mercia Mudstone Group in the British Isles occurs on the Devon coast, between Sidmouth and Seaton (Howard et al.,
2008): Figure 2. The composite log of Gallois, (2018) is used as a standard for our data outputs: raw field measurements and photographs of representative facies where spectral gamma ray measurements were taken, are available on request. 556 spectral gamma-ray measurements were taken every metre from the entire (bar some inaccessible/unexposed horizons) Mercia Mudstone Group of the type section in August 2018, using both a Georadis GT-40 Gamma Ray Analyser and Scintrex GIS-5. The methodology of Slatt et al., (1986) was used to standardise the data, wherein five 10-second (time window) measurements were taken for total count, $K, U$ and Th, the highest and lowest value discarded and the remaining three averaged. The Slatt et al. (1986) methodology has been used in many subsequent studies (for example, Bessa and Hesselbo, 1997) but not updated, due to its robustness and the use of automated spectral gamma ray detectors that convert total counts to American $\mathrm{Pe}$ troleum Institute (API) units. The geostatistical reliability of $K, U$ andTh measurements from spectral gamma ray tools, has however been tested, and found to be entirely efficient if deployed robustly (Guagliardi et al., 2013). Results are shown in Figures 3 and 4: Figure 3 shows the raw spectral data, whilst Figure 4 shows in detail the ratios that concern us here in terms of testing the palaeoclimate-related pattern predicted from other studies. Where unexposed, or complicated by 

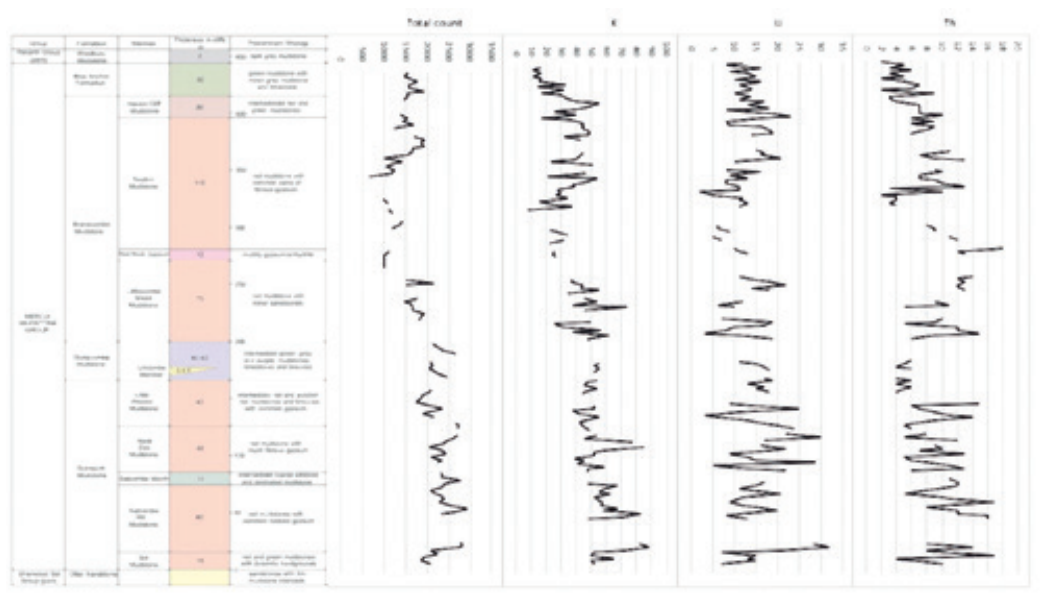

Figure 3. Summary lithostratigraphy (after Gallois, 2018) and counts per second spectral gamma-ray log data for the Triassic (and earliest Jurassic), Devon coast, SW England. Total count data taken at $20-50 \mathrm{~cm}$ variance in height from K, U and Th, as two spectral gamma detectors were used simultaneously, hence there are more data points in the total count than the spectral measurements.

Figura 3. Resumen litoestratigráfico (según Gallois, 2018) y conteo por segundo de los datos de diagrafías de rayos gamma espectral para el Triásico (y Jurásico Inferior), costa de Devon, SW de Inglaterra. Datos de conteo total tomados a $20-50 \mathrm{~cm}$ de varianza en altura para K, U y Th, ya que se utilizaron simultáneamente dos detectores gamma espectral, de modo que hay más puntos de datos en el conteo total que medidas espectrales.

faulting, correlation was achieved using oblique aerial imagery, taken using a Mavic Pro Unmanned Aerial Vehicle (UAV, or drone), fitted with standard 12-megapixel, gimble-controlled camera (Figures 5, 6, 7). All flights were made under Civil Aviation Authority guidance and outside of restricted commercial and military flight zones/times by an accredited drone pilot.

\section{Results}

Total count gamma-ray output decreases through the Mercia Mudstone Group succession, as seen in neighbouring boreholes (Lott et al., 1982. Gallois, 2003), with the lowest output in the Seaton Mudstone Member (likely Norian in age). K output broadly reflects this pattern, with elevated counts in the Hook Ebb Mudstone and Littlecombe Shoot Mudstone members, some of which are coincident with the more variable $\mathrm{U}$ contents/outputs. Th shows a highly variable output, overall diminishing up-section like total count. Th/K reverses this pattern (Fig. 4), with low ratios below the Carnian Dunscombe Mudstone Formation, becoming variable but on average higher above. Th/K is more difficult to summarise, with peaks above and below the Dunscombe Mudstone Member and none in the lower or upper members of the Mercia Mudstone Group. Gamma-ray total-count signatures in the Wessex Basin boreholes are more complex than the outcrop (Lott et al., 1982; Gallois, 2003; Gallois and Porter, 2006), due to the lower number of counts per metre of stratigraphy at outcrop. A good example is comparison of this outcrop work to the gamma-ray log from the Wiscombe Park No. 2 borehole (recorded in Gallois and Porter, 2006), the latter showing a highly variable gamma-ray output. Most specifically, the crude vertical spacing (roughly $1 \mathrm{~m}$ ) of these outcrop data, together with parts of the section being inaccessible or covered by rock-fall and scree (Fig. 6), makes definition of individual gamma-ray peaks and troughs impossible. For instance, there are only 9 measurements in the Dunscombe Mudstone Formation $(40+m$ thick and including a wide range of lithologies), none of which are across the boundaries with the adjacent formations. Instead, it is more reliable to interpret these crude outcrop data in terms of log motif analysis (Nazeer et al., 2016) and by examining the spectral components of $\mathrm{K}, \mathrm{U}$ and Th (this work).

\section{Discussion}

- Total count gamma-ray output, $\mathrm{K}$ and $\mathrm{U}$ from the Mercia Mudstone Group succession decreases (variably) through the section from base to top, reflecting a diminution in clastic supply from the hinterlands to the north and west (Hounslow et al. 2012).

- The consistent decrease in total count, $\mathrm{K}$ and $\mathrm{U}$ suggests an overall depositional control on these sources of gamma-ray radiation, whilst peaks and troughs in the data may reflect heavy-mineral layers, diage- 

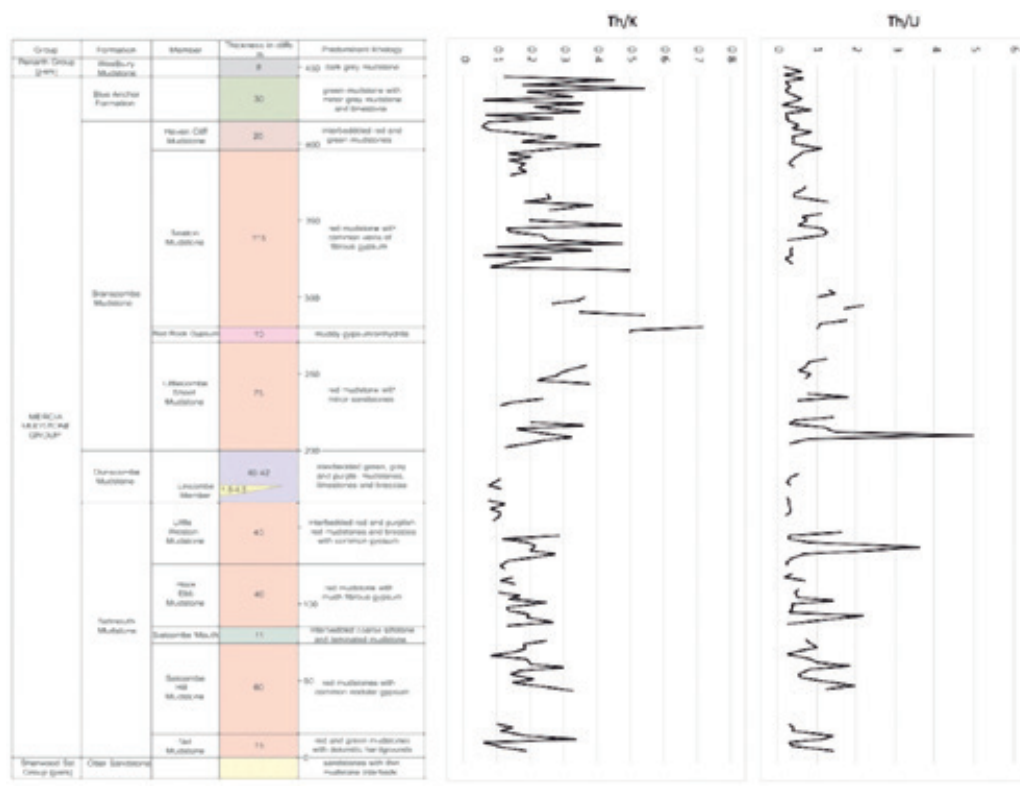

Figure 4. Detail of the $\mathrm{Th} / \mathrm{K}$ and $\mathrm{Th} / \mathrm{U}$ ratios calculated from data on Fig. 3, with expanded $\mathrm{X}$ Axis to facilitate analysis of ratio changes through the succession. Comments as for Figure 3.

Figura 4. Detalle de los ratios $T h / K$ y Th/U calculados a partir de datos en la Fig. 3, con el eje X expandido para facilitar el análisis de los cambios de los ratios a lo largo de la sucesión. Los comentarios son los mimos que los de la Figura 3.
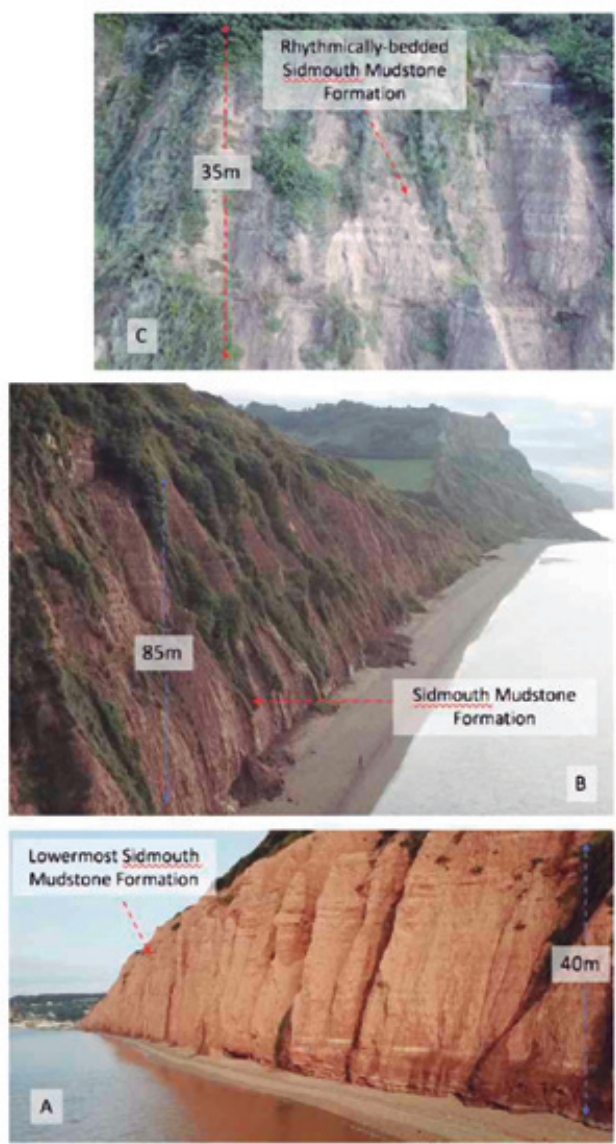

Figure 5. Oblique aerial images of the lower parts of the succession (Sidmouth Mudstone Formation, Ladinian), showing the cyclicity analysed by Miller et al. (2017) as representing Precessional Orbital Cycles, changes in which are recorded here in the spectral gamma-ray logs.

Photos placed in stratigraphic order.

5A: Offshore of Pennington Point (see Figure 2 for location), view to the west, the town of Sidmouth (marked by + on Figure 2): 5B: offshore of Pennington Point (see Figure 2 for location), view to the east, Dunscombe Cliff on the far right of the image; 5C: detail of rhythmically-bedded Sidmouth Mudstone Formation. The photos in Figs 5-7 were taken at a time when the cliffs were in poor condition with the boundaries partly obscured by wash from the overlying formations.

Figura 5. Imágenes aéreas oblicuas de las partes inferiores de la sucesión (Sidmouth Mudstone Formation, Ladiniense), mostrando la ciclicidad analizada por Miller et al. (2017) como el ciclo orbital de precesión, cuyos cambios se registran aquí en las diagrafías de rayos gamma espectral. Las fotos están colocadas en orden estratigráfico.

5A: Costa afuera de Pennington Point (ver Figura 2 para localización), vista desde el oeste, la ciudad de Sidmouth (marcada con + en la Figura 2), 5B: costa afuera de Pennington Point (ver Figura 2 para localización), vista desde el este, Dunscombe Cliff está en la parte más a la derecha de la imagen; 5C: detalle de la rítmicamente estratificada Sidmouth Mudstone Formation. Las fotos en las figuras 5-7 se tomaron en un tiempo en el que los acantilados estaban en malas condiciones con los límites parcialmente oscurecidos por el lavado de las formaciones suprayacentes. 

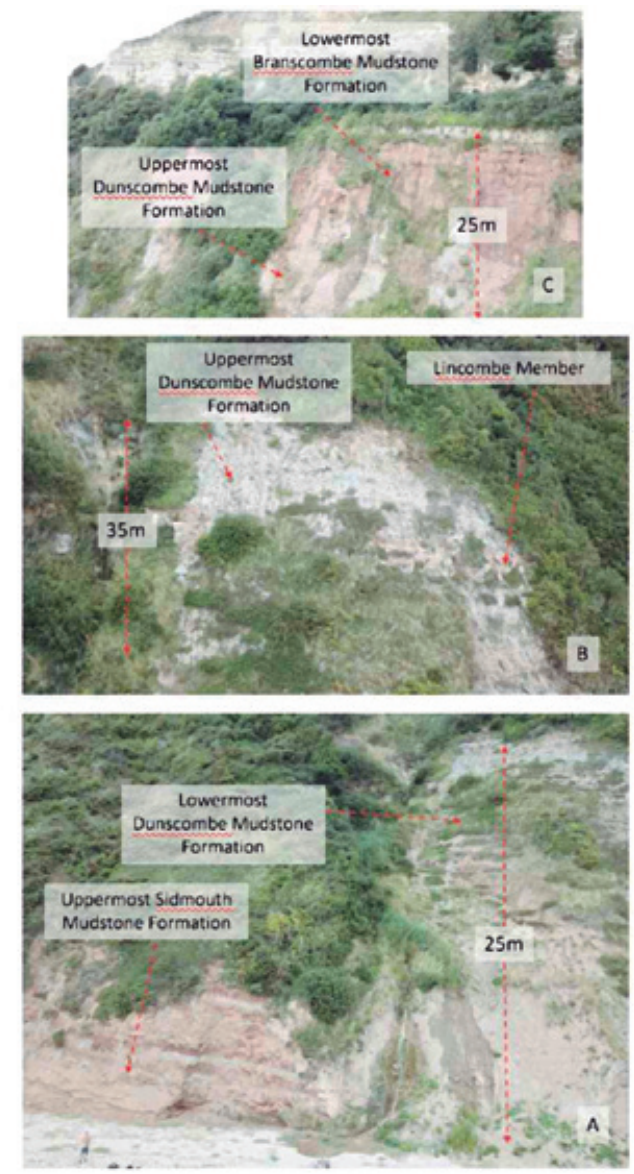

Figure 6. Oblique aerial images of the middle parts of the succession, concentrating on the Carnian Dunscombe Mudstone Formation - the grey, reduced representation of the Carnian Pluvial Episode (CPE).

Photos placed in stratigraphic order.

6A: the contact of the top (uppermost) Sidmouth Mudstone Formation and base (lowermost) Dunscombe Mudstone Formation; 6B: detail of the Dunscombe Mudstone Formation, showing the Lincombe Member (calcareous); 6C: the contact of the top Dunscombe Mudstone Formation and overlying (lowermost) Branscombe Mudstone Formation, possibly the Carnian - Norian transition (Miller et al. [2017]).

Figura 6. Imágenes aéreas oblicuas de las partes medias de la sucesión, concentrándose en el Dunscombe Mudstone Formation del Carniense - la gris, reducida representación del Episodio Pluvial Carmiense (CPE).

6A: el contacto del techo superior de la Sidmouth Mudstone Formation y el muro de la Dunscombe Mudstone Formation; 6B: detalle de la Dunscombe Mudstone Formation; 6C: el contacto del techo de la Dunscombe Mudstone Formation y el muro de la Branscombe Mudstone Formation, muy probablemente la transición Carniense-Noriense (Miller et al. [2017]).

netic concentration, or in the case of carbonate-rich beds, dilution of the $\mathrm{K}$ and $\mathrm{U}$ content. Peaks in $\mathrm{K}$ may reflect some residual content from evaporite-bearing units, whilst Th concentrations maybe associated with Th-rich reduction spots focussed on organic concentrations (Spinks et al., 2010).

- The gamma-log reflects changing lithological content, based on overall lithological changes, as well as
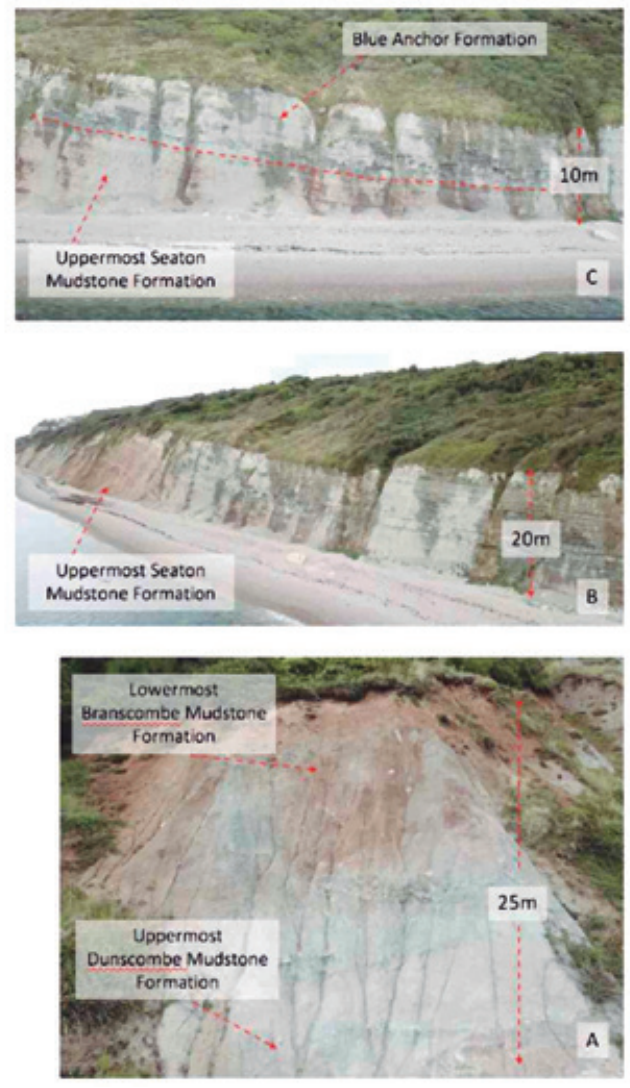

Figure 7. Oblique aerial and orthogonal images of the upper parts of the succession ( Norian - Rhaetian), showing the Precessional Orbital Cycles, changes in which are recorded here in the spectral gamma-ray logs.

7A: the contact of the top Dunscombe Mudstone Formation (Carnian) and overlying (lowermost - possibly Norian) Branscombe Mudstone Formation: $\mathrm{Th} / \mathrm{K}$ increases from this contact, upwards for 20m; 7B: the uppermost Seaton Mudstone Formation (Norian); 7C: contact (marked in red dashed line) of the Seaton Mudstone and Blue Anchor Formation (Norian - Rhaetian).

Figura 7. Imágenes aéreas oblicua y orthogonal de la partes superiors de la sucesión ( Noriense - Retiense), mostrando los Ciclos Orbitales de Precesión, cuyos cambios han quedado registrados aquí en la diagrafías de rayos gamma espectrales.

7A: el contacto de la Dunscombe Mudstone Formation (Carniense) superpuesta a la (la parte más baja posiblemente Noriense) Branscombe Mudstone Formation: Th/K se incrementa en este contacto en dirección ascendente para unos 20m; 7B: la Seaton Mudstone Formation (Noriense); 7C: contacto (marcado con una línea roja discontínua) de la Seaton Mudstone y Blue Anchor Formation (Noriense-Retiense).

comparison to changing clay mineral contents: the masking effect of heavy mineral layers, carbonate dilution and the $\sim 1 \mathrm{~m}$ spacing of measurement points, makes bed-by-bed analysis problematic, but if unmasked, perhaps the gamma-ray signal contains information on the orbital cycles themselves, as suggested from the gamma-ray log of the Wiscombe Park No. 2 borehole analysed in Miller et al. (2017). 
- Total count gamma-ray log motifs from the succession are comparable in parts to borehole gamma-ray logs from adjacent boreholes (Lott et al., 1982; Gallois, 2003; Gallois and Porter, 2006), showing that the results for this output are not isolated to the Devon outcrops, but may be extended through the Wessex Basin. Spectral gamma-ray data was not gathered in these boreholes, so we do not know what changes in individual radioisotope contents or their ratios show. However, a reconnaissance spectral gamma-ray log through road-cutting successions some $40-60 \mathrm{~km}$ north of the section measured here show similar patterns. To establish better what the spectral gamma-ray logs mean for Late Triassic environmental change, logs comparable to those presented here are needed from other locations in the Germanic Basin, Newark and perhaps the Tethyan successions.

- The change in spectral gamma-ray output from below to above the (Carnian) Dunscombe Mudstone Formation occurs at the same horizon Jeans (1978) observed a change from mica/chlorite-dominated clay mineral content to one of smectite-mica and sepiolite, then back to mica/chlorite above.

- If the Carnian Dunscombe Mudstone Formation is the result of overall more humid climate, or indeed the five humid climate pulses (Miller et al., 2017), the Th/K and Th/U ratios should be elevated, in line with increased weathering and $K$ and $U$ depletion in the hinterlands. This was not recorded in the formation, but is observed above. An initial assumption would be that either the unusual clay mineral content of the Mercia Mudstone does not house $K$ and $U$ in the same way as other unmetamorphosed Phanerozoic successions (Van Buchem et al., 1992), or that increased humidity did not occur at this time, perhaps throwing some doubt on the nature of Carnian events and the very existence of the CPE in the Dorset Triassic hinterlands, contradicting pollen and isotope records from other European successions (see references above). However, the duration of the CPE (Miller et al., 2017) and elevated Th/K (although not Th/U) above the Dunscombe Member may provide an explanation. The CPE in this section, and elsewhere (e.g. Italy and China) is considered to be about 1 million years in duration. Perhaps in the arid-zone climates of this part of Pangaea, this was simply not long or weathering-intense enough for the depletion of $\mathrm{K}$ to occur. Instead, perhaps the change in Th/K above the Dunscombe Mudstone Member is a residence time or 'lag' effect. During Dunscombe deposition, the more reduced and mixed-layer clay deposits were still retaining the
$\mathrm{K}, \mathrm{U}$ and Th contents of the sediments produced and deposited in the Sidmouth Mudstone (below), but after the 1 million year interval(s) of humidity, and for sometime afterwards, humidity did deplete $\mathrm{K}$ enough to affect the Th/K ratio. This is not observed in the Th/U ratio, perhaps as a result of more stable $U$ hosts in the hinterland rocks being weathered. Whilst both $\mathrm{K}$ and $\mathrm{U}$ are known to be soluble in aqueous solution, $\mathrm{K}$ is known to be more mobile when feldspars are broken down to clays (Osmond and Ivanovitch, 1992). A further consideration to make is the cause of the CPE itself, with volcanic-induced changes in $\mathrm{CO} 2$ being invoked: whilst large volcanic activity is recorded for the Carnian in many locations globally, perhaps these were part of a larger, more gradual picture of palaeoenvironmental change involving rifting, associated influx of marine waters through rift corridors and hence a more maritime climate in the interiors to Pangaea. There is convincing published evidence that the Dunscombe Mudstone was deposited in a wetter climate than the underlying and overlying formations and that this is a correlative of the CPE. An alternative explanation than those given above is that the measurements plotted in Fig. 3 contain too many gaps and are too widely spaced to provide a reliable picture of the changes through time. However, the overall change in Th/K and Th/U through the Sidmouth, the Dunscombe, then Branscombe mudstones is not dependant on vertical sample spacing.

- This work places the known cyclicity of the Late Triassic (shown in Figures 5 and 7) into a broader context: because of the popularity/significance of the CPE as a concept, many papers concentrate on this period of geological time only - and justifiably. However, the importance and nature of the CPE can also be understood in terms of the longer term changes above and below, shown here through the use of spectral gamma-ray logs, specifically the elevated counts in Sidmouth Mudstone, but diminish above the Dunscombe Mudstone, and the elevated Th/K above the Dunscombe Mudstone.

\section{Acknowledgements}

Chris Leech (Geomatrix Systems) kindly provided advice on the spectral gamma-ray detection equipment. The permission of the National Trust for England and Wales (Salcombe Hill), Sea Shanty Holidays (Branscombe) and Devon County Council (Seaton) is also gratefully acknowledged. 


\section{References}

Arche, A. and Lopez-Gomez, J. 2014. The Carnian Pluvial Event in Western Europe: New data from Iberia and correlation with the Western Neotethys and Eastern North America-NW Africa regions. Earth Science Reviews, 128, 196-231.

Arthurton, R. S. 1980. Rhythmic sedimentary sequences in the Triassic Keuper Marl (Mercia Mudstone Group) of Cheshire, northwest England. Geological Journal 15, 43-58.

Aigner T, and Bachmann G.H. 1992. Sequence stratigraphic framework of the German Triassic. Sedimentary Geolo$g y, 80,115-135$.

Baranyi, V., Miller, C., Ruffell, A., Hounslow, M.W. and Kürschner, W.M. 2018. A continental record of the Carnian Pluvial Episode (CPE) from the Mercia Mudstone Group (UK): palynology and climatic implications. Journal of the Geological Society, London, 176, 149-166.

Bernardi, M., Gianolla, P., Massimo, F., Petti, P.M. and Benton, M.J. 2018. Dinosaur diversification linked with the Carnian Pluvial Episode. Nature Communications, 2018, 9 (1).

Bessa, J.L., and Hesselbo, S.P. 1997. Gamma-ray character and correlation of the Lower Lias, SW Britain. Proceedings of the Geologists' Association, 108, 113-129.

Chua, R., Wua, H., Zhuc, R., Fang, Q., Dengc, S., Cuic, J., Yanga, T., Lia, H., Caoa, L. and Zhanga, S. 2020. Orbital forcing of Triassic megamonsoon activity documented in lacustrine sediments from Ordos Basin, China. Palaeogeography, Palaeoclimatology, Palaeoecology, 541, 109542.

Dal Corso, J., Mietto, P., Newton, R.J., Pancost, R.D., Preto, N., Roghi, G. and Wignall, P.B. 2012 Discovery of a major negative $\delta 13 \mathrm{C}$ spike in the Carnian (Late Triassic) linked to the eruption of Wrangellia flood basalts. Geology, 40, 79--82.

Dal Corso, J., Benton, M.J., Bernardi, M., Franz, M., Gianolla, P. Hohn, S., Kustatscher, E., Merico, A., Roghi, G., Ruffell, A., Ogg, J.G., Preto, N., Schmidt, A.R., Seyfullah, L.J., Simms, M.J., Zhiqiang, S. and Zhang. Y. 2018. First Workshop on the Carnian Pluvial Episode (CPE): a report. Albertiana, 44, 49-57.

Elliott, R. E. 1961. The Stratigraphy of the Keuper Series in Southern Nottinghamshire. Proceedings of the Yorkshire Geological and Polytechnic Society, 33, 197-234.

Franz, M., Nowak, K., Berner, U., Heunisch, C., Bandel, K., Röhling, H-G. M. and Wolfgramm, M. 2014. Eustatic control on epicontinental basins: The example of the Stuttgart Formation in the Central European Basin (Middle Keuper, Late Triassic). Global and Planetary Change, 122, 305-329.

Franz, M., Kustatscher, E., Heunisch, C., Niegel, S. and Röhling, H.-G., 2018. The Schilfsandstein and its flora; arguments for a humid mid-Carnian episode? Journal of the Geological Society, 176, 133-148.
Gallois, R. W. 2003. The distribution of halite (rock-salt) in the Mercia Mudstone Group (mid to late Triassic) in South-west England. Geoscience in South-west England, 10, 383-389.

Gallois, R.W. 2018. The stratigraphy of the Permo-Triassic rocks of the Dorset and East Devon Coast World Heritage Site, U.K. Proceedings of the Geologists' Association, 129, 392-420.

Gallois, R.W. and Porter, R.J. 2006. The stratigraphy and sedimentology of the Dunscombe Mudstone Formation (Late Triassic) of south-west England. Geoscience in south-west England, 11, 174-182.

Gianolla, P., Roghi, G. and Ragazzi, E., 1998. Upper Triassic amber in the Dolomites (northern Italy). A paleoclimatic indicator? Rivista Italiana di Paleontolologia e Stratigrafia, 104, 381-390.

Guagliardi, I., Buttafuoco, G., Apollaro, C., Bloise, A., De Rosa, R., and Cicchella, D. 2013. Using gamma-ray Spectrometry and Geostatistics for Assessing Geochemical Behaviour of Radioactive Elements in the Lese Catchment (southern Italy), International Journal of Environmental Research, 7(3), 645-658.

Howard, A.S., Warrington, G., Ambrose, K. and Rees, J.G. 2008. A Formational Framework for the Mercia Mudstone Group (Triassic) of England and Wales. British Geological Survey Research Report, RR/08/04. 33pp.

Hounslow, M.W., McKie, T. and Ruffell, A.H. 2012. Permian to late Triassic post-orogenic collapse and rifting, arid deserts, evaporating seas and mass extinctions (Chapter 16). In: Woodcock, N. and Strachan, R. (eds.) Geological History of Britain and Ireland, $2^{\text {nd }}$ Edition. Wiley Blackwell Science. pp. 315-340.

Hurst, A. 1990. Natural gamma ray spectrometry in hydrocarbon-bearing sandstones from the Norwegian continental shelf. In: Hurst, A., Lovell, M. and Morton, A. (Editors) Geological Applications of Wireline Logs. Geology Society London Special Publication, 48, p.211-222.

Jeans, C.V. 1978. The origin of the Triassic clay assemblages of Europe with special reference to the Keuper Marl and Rhaetic of parts of England. Philosophical Transactions of the Royal Society of London, Series A 289, 549-639.

Kemp, D.B. and Coe, A.L. 2007 A nonmarine record of eccentricity forcing through the Upper Triassic of southwest England and its correlation with the Newark Basin astronomically calibrated geomagnetic polarity time scale from North America, Geology, 35 (11): 991 - 994.

Kent, D.V., Olsen, P.E., Rasmussen, C., Lepre, C., Mundil, R., Irmis, R.B., Gehrels, G.E., Giesler, D., Geissman, J.W. and Parker, W.G., 2018. Empirical evidence for stability of the 405-kiloyear Jupiter-Venus eccentricity cycle over hundreds of millions of years. PNAS, 2018115 (24) 6153-6158.

Kozur, H., 1975. Probleme der Triasgliederung und Parallelisierung der germanischen und tethyalen Trias. Teil II: 
Anschluß der germanischen Trias an die international Triasgliederung. Freiburger Forstliche Forschung, C304, 51-77.

Kozur, H. and Bachman, G.H. 2010. The Middle Carnian wet intermezzo of the Stuttgart Formation (Schilfsanstein), Germanic Basin. Palaeogeography, Palaeoclimatology, Palaeoecology, 290, 107-119.

Litwin, R.J., Traverse, A. and Ash, S.R., 1991. Preliminary palynological zonation of the Chinle Formation, southwestern U.S.A., and its correlation to the Newark Supergroup (eastern U.S.A.). Review of Palaeobotany and Palynolo$g y, 68,269-287$.

Lott, G.K., Sobey, R.A., Warrington, G. and Whittaker, A. 1982. The Mercia Mudstone Group (Triassic) in the western Wessex Basin. Proceedings of the Ussher Society, 5, 340-346

Lucas, S.G., Tanner, L.H., Kozur, H.W., Weems, R.E. and Heckert, A.B. 2012. The Late Triassic timescale: Age and correlation of the Carnian-Norian boundary. Earth Science Reviews, 114, 1-18.

Lucas, S.G. and Tanner, L.H. 2018. Record of the Carnian wet episode in strata of the Chinle Formation, western USA. Journal of the Geological Society, 175, 1004-1011.

Miller, C., Peterse, F., da Silva, A-C., Baranyi, V., Reichert, G.J. and Kürschner, W.M. 2017. Astronomical age constraints and extinction mechanisms of the late Triassic Carnian crisis. Nature Scientific Reports, 7, 2557.

Milroy, P., Wright, V.P. and Simms, M.J. 2019. Dryland continental mudstones: deciphering environmental changes in problematic mudstones from the Upper Triassic (Carnian to Norian) Mercia Mudstone Group, south-west Britain. Sedimentology, 66, 2557-2589.

Mueller, S., Krystyn, L. and Kürschner, W.M. 2016. Climate variability during the Carnian Pluvial Phase - A quantitative palynological study of the Carnian sedimentary succession at Lunz am See, Northern Calcareous Alps, Austria. Palaeogeography, Palaeoclimatology, Palaeoecology, 441, 198-211.

Myers, K.J. and Bristow, C.S. 1989. Detailed sedimentology and gamma ray log characteristics of a Namurian deltaic succession II: Gamma ray logging. In: M.K.G. Whateley and K.T. Pickering (Editors) Deltas: Sites andTraps for Fossil Fuels. Geological Society Special Publication 41, 81-88.

Nakada, R, Ogawa, K., Suzuki, N., Takahashi, S. and Takahashi, Y. 2014. Late Triassic compositional changes of aeolian dusts in the pelagic Panthalassa: Response to the continental climatic change. Palaeogeography, Palaeoclimatology, Palaeoecology, 393, 61-75.

Nazeer, N, Abbasi, S.A. and Solangi, S.H. 2016. Sedimentary facies interpretation of Gamma Ray (GR) log as basic well logs in Central and Lower Indus Basin of Pakistan. Geodesy and Geodynamics, 7, 432-443.

Olsen, P. E., 1984. Periodicity of lake-level cycles in the Late Triassic Lockatong Formation of the Newark Basin. In:
Berger, A., et al., eds., Milankovitch and climate, Part 1: Boston, Massachusetts, D. Reidel Publishing Company, p. 129-146.

Olsen, P.E. and Kent, D.V. 1999, Long-period Milankovitch cycles from the Late Triassic and Early Jurassic of eastern North America and their implications for the calibration of the early Mesozoic time scale and the long-term behaviour of the planets. Philosophical Transactions of the Royal Society of London (Series A), 357, 1761-1787.

Olsen, P.E., Kent, D.V., Cornet, B., Witte, W.K. and Schlisse, R.W. 1996. High-resolution stratigraphy of the Newark Basin (Early Mesozoic, Eastern North America). Geological Society of America Bulletin, 108, 40-77.

Olsen, P. E., Geissman, J.W., Kent, D. V., Gehrels, G. E., Mundil, R., Irmis, R. B., Lepre, C., Rasmussen, C., Giesler, D., Parker, W. G., Zakharova, N., Kürschner, W. M., Miller, C., Baranyi, V., Schaller, M. F., Whiteside, J. H., Schnurrenberger, D., Noren, A., Brady Shannon, K., O'Grady, R., Colbert, M. W., Maisano, J., Edey, D., Kinney, S.T., Molina-Garza, R., Bachman, G. H., Sha, J. and the CPCD team. 2018. Chronology of Triassic continental environmental change from western North America, Scientific Drilling, 24, 15-40.

Osmond, J.K. and Ivanovich, M. 1992 Uranium-series mobilisation and surface hydrology. In: Ivanovich, M. and Harmon, R.S. (eds), Uranium-series Disequilibrium: Applications to Earth, Marine and Environmental Sciences. Clarendon Press, Oxford. p. 259-289.

Preto, N., Willems, H., Guaiumi, C. and Westphal, H. 2013. Onset of significant pelagic carbonate accumulation after the Carnian Pluvial Event (CPE) in the western Tethys. Facies, 59, 891-914.

Reinhardt, L., and Ricken, W. 2000. The stratigraphic and geochemical record of Playa Cycles: monitoring a Pangaean monsoon-like system (Triassic, Middle Keuper, southern Germany). Palaeoecology, Palaeogeography, Palaeoclimatology, 161, $205-227$.

Ridgwell, A. 2005. A mid Mesozoic revolution in the regulation of ocean chemistry, Marine Geology, 217, 339-357.

Roghi, G. 2004. Palynological investigations in the Carnian of the Cave del Predil area (Julian Alps, NE Italy). Review of Palaeobotany and Palynology, 132, 1-35.

Rostasi, A., Raucsik, B. and Varga, A. 2011. Palaeoenvironmental controls on the clay mineralogy of Carnian sections from the Transdanubian Range (Hungary). Palaeogeography, Palaeoclimatology, Palaeoecology, 300, 101-112.

Ruffell, A.H. and Worden, R.H. 2000 Palaeoclimate analysis using spectral gamma ray data from the Aptian (Cretaceous) of southern England and southern France. Palaeoecology, Palaeogeography, Palaeoclimatology, 154, 313- 325

Ruffell, A., Simms, M.J. and Wignall, P.B. 2015. The Carnian Humid Episode of the late Triassic: a review. Geological Magazine, 153, 271-284. 
Schlager, W. and Schöllnberger W. 1974. Das Prinzip stratigraphischer Wendenin der Schichtenfolge der Nordlichen Kalkalpen. Mitteilungen der Geologischen Gesellschaft Wien, 66/67, 165-193.

Simms, M.J. and Ruffell, A.H. 1989. Synchroneity of climatic change and extinctions in the late Triassic. Geology, 17, 265-268.

Slatt, R.M., Jordan, D.W., D'Agostino, A. and Gillespie, R.H. 1992 Outcrop gamma ray logging to improve understanding of subsurface well log correlations. In: Hurst, A., Griffiths, C.M. and Worthington, F. (Editors) Geological Applications of Wireline Logs II. Geological Society Special Publication, 65, 3-19.

Spinks, S.C., Parnell, J.T. and Bowden, S.A. 2010. Reduction spots in the Mesoproterozoic age: implications for life in the early terrestrial record. International Journal of Astrobiology, 9, 209-216.

Tollmann A (1976) Analyse des klassischen nordalpinen Mesozoikums: Stratigraphie, Fauna und Fazies der Nordlichen Kalkalpen. Springer, Berlin Heidelberg New York

Tucker, M.E. and Benton, M.J. 1982. Triassic environments, climates and reptile evolution. Palaeogeography, Palaeoclimatology, Palaeoecology, 40, 361-379.

Vollmer, T., Ricken, W., Weber, M., Tougiannidis, N. Röhling, H.G. and Hambach, U., 2008. Orbital control on UpperTriassic Playa cycles of the Steinmergel-Keuper (Norian): A new concept for ancient playa cycles. Palaeogeography, Palaeoclimatology, Palaeoecology, 267, 1-16.

Warrington, G. and Scrivener, R.C. 1980. The Lyme Regis (1901) Borehole succession and its relationship to the sequence of the east Devon coast. Proceedings of the Ussher Society, 5, 124-132.
Weedon, G.P., Jenkyns, H.C., Coe, A.L. and Hesselbo, S.P. 1999. Astronomical calibration of the Jurassic time-scale from cyclostratigraphy in British mudrock formations. Philosophical Transactions of the Royal Society A, 357, 1787-1813.

Van Buchem, F.S.P., Melynk, D.H., and McCave, I. 1992 Chemical cyclicity and correlation of Lower Lias mudstones using gamma ray logs, Yorkshire, UK. Journal of the Geological Society, London, 149, 991 - 1002.

Visscher, H., and Van der Zwan, C.J., 1981, Palynology of the circum-Mediterranean Triassic; phytogeographical and palaeoclimatological implications: Geologische Rundschau, 70, p. 625-634.

Visscher, H., Van Houte, M., Brugman, W.A. and, Poort, P.R., 1994. Rejection of a Carnian (Late Triassic) "pluvial event" in Europe. Review of Palaeobotany and Palynology, 83, 217-226.

von Alberti, F. A. 1834. Monographie des Bunten Sandsteins, Muschelkalks und Keupers, und die Verbindung dieser Gebilde zu einer Formation (Stuttgart-Tübingen: Cotta), 1834.

Zhang, Y., Li, M., Ogg, J.G., Montgomery, P., Huang, C., Chen Z.-Q.., Shi, Z., Enos, P. and Lehrmann, D.J., 2015. Cycle-calibrated magnetostratigraphy of middle Carnian from South China: Implications for Late Triassic time scale and termination of the Yangtze Platform. Palaeoecology, Palaeogeography, Palaeoclimatology, 436, 135-166.

Zhang, Y., Ogg, J.G., Franz, M., Bachmann, G.H., Szurlies, M., Röhling, H.-G., Li, M., Rolf, C. and Obst, K. 2020. Carnian (Late Triassic) magnetostratigraphy from the Germanic Basin allowing global correlation of the Mid-Carnian Episode. Earth and Planetary Science Letters, 541, 116275.

Recibido: julio 2019

Revisado: noviembre 2019

Aceptado: enero 2020

Publicado: marzo 2021 